\title{
Implementation of Blended Learning with A STEM Approach to Improve Student Scientific Literacy Skills During The Covid-19 Pandemic
}

\author{
Hana Lestari ${ }^{*}$, Ima Rahmawati ${ }^{1}$, Ridwan Siskandar², Hadi Dafenta ${ }^{3}$ \\ ${ }^{1}$ Faculty of Teacher Training and Education, IAI Sahid, Bogor, Indonesia \\ ${ }^{2}$ Computer Engineering Study Program, College of Vocational Studies, IPB University, Bogor, Indonesia \\ ${ }^{3}$ Ministry of Agriculture, Indonesia
}

DOI: $10.29303 /$ jppipa.v7i2.654

\section{Article Info}

Received : February 27th, 2021

Revised : April 14th 2021

Accepted: April 16

\begin{abstract}
The Covid-19 pandemic has a positive impact on the blended learning system, especially the synchronous and asynchronous aspects of online learning. This study aims to obtain information about how to apply the blended learning model with the STEM approach to students' scientific literacy skills during the COVID pandemic. The research method used was pre-experiment with one group pretest-posttest design. This research was conducted at SMAN 1 Bojong Gede, Bogor Regency in the academic year 2020/2021. The research sample used two class $X$ which have been selected as purposive sampling. The instrument used in this study was a student science literacy test containing 20 question items. The data processing technique was carried out descriptively by calculating the mean and percentage of each item to obtain a description of the students' scientific literacy skills, then the data were analyzed inferentially with paired sample t-test using SPSS version 22 software, to see differences in scientific literacy before and after blended learning with the STEM approach. The results showed that in general, the average scientific literacy skills of students from the application of the blended learning model with the STEM approach had an average score of 85.50 in the good category. For students to have a better understanding of scientific literacy, students' understanding of science should be continuously trained through the blended learning model with the STEM approach.
\end{abstract}

Keywords: blended learning; scientific literacy skills; STEM

Citation: Lestari, H., Rahmawati, I., Siskandar, R., \& Dafenta, H. (2021). Implementation of Blended Learning with A STEM Approach to Improve Student Scientific Literacy Skills During The Covid-19 Pandemic. Jurnal Penelitian Pendidikan IPA, 7(2), 224-231. doi:https://doi.org/10.29303/ippipa.v7i2.654

\section{Introduction}

Biology learning is learning that provides direct and meaningful learning experiences to develop student competencies to better understand the natural surroundings (Rahmadani et al., 2021). Broadly speaking, biology learning has three main components in learning, namely scientific attitudes, scientific processes, and scientific products. Concerning learning, biology should not only be fixated on concepts. However, it provides direct experience in the development of mastery of products, processes, and scientific attitudes or more broadly in mastering scientific literacy (Arlis et al., 2020; Zuhara et al., 2019).

Scientific literacy is knowledge and understanding of scientific concepts and processes needed to solve problems and draw evidence-based conclusions to understand and make decisions regarding nature and changes made to nature through humans(Komalasari et al., 2019). Scientific literacy is very important to prepare the skills that students in the 21st century must have from elementary school to college level, which include critical thinking, creative, 
collaborative, and communication skills (Jamaluddin et al., 2019; Ramdani et al., 2019).

Based on the results of the evaluation of the Program for International Student Assessment (PISA), in 2015, Indonesia ranked at the bottom of the 72 participating countries, Indonesia ranked 8th from the bottom. PISA is an international scale evaluation, held in 50 countries to measure and compare the reading, math, and science literacy of students of one country with other participating countries so that it can provide an overview of the strengths and weaknesses of each country's education system. PISA evaluation data shows that the scientific literacy skills of students in Indonesia are in the low category of the Low International Benchmark (Yuliati, 2017). The low scientific literacy of students in Indonesia is caused by several factors including The low understanding of students towards the nature of science or Nature of science (NoS) (Lestari \& Widodo, 2021); students understand science in terms of theory, students have not been able to apply science concepts in everyday life (Lestari et al., 2019); The low ability of students to read, interpret data in the form of pictures, tables, diagrams, and other forms of presentation; The low ability of students in higher-order thinking such as solving problems, scientific reasoning, critical thinking and creative thinking (Hasasiyah et al., 2019; Sopandi, 2019).

Students' scientific literacy skills can be developed and improved with appropriate methods and supported by adequate technology (Fitriyana et al., 2020; Lestari et al., 2020). Technology is very important learning support in learning, especially when it is currently in the Covid19 pandemic. It has been almost 1 year, Indonesia has been hit by the Covid 19 pandemic, which requires people to worship, study and work from home. The community has entered a new life order called the New Normal in the face of the Covid 19 pandemic. New Normal is a normal community life by continuing to carry out various activities but with a lifestyle that strictly applies health protocols to prevent the spread and transmission of Covid-19 (Jarwati \& Priskawati, 2020). The health protocol in question is to diligently wash hands with soap, use masks, maintain distance and adopt a clean and healthy lifestyle.

In the new normal era, learning in high school entered normal learning, so it is necessary to implement a learning system that can integrate online and offline learning but still apply health protocols. Online learning is learning that is carried out using the internet so that teachers and students do not need to meet face to face in the learning process (Setiawan \& Iasha, 2020). Meanwhile, offline learning is learning outside the network that does not take advantage of internet access (Fauzi \& Sastra Khusuma, 2020). One learning model that can be applied to new normal learning and can improve students' scientific literacy skills is blended learning with the STEM approach.

Blended learning is a mixed learning pattern between face-to-face and online learning (Lestari \& Siskandar, 2020). Blended learning is the new normal era that uses online media by utilizing multimedia, both synchronous and asynchronous (Berga et al., 2021; Dhawan, 2020). Synchronous learning is a form of learning with direct interaction between students and teachers as well as using online forums such as conferences and online chats. Meanwhile, asynchronous is a form of learning indirectly (not at the same time) using an independent learning approach (Borup et al., 2019; Richardson et al., 2020).

Blended learning has the characteristics of learning space, namely, direct synchronous, virtual synchronous, collaborative asynchronous, and independent asynchronous. Synchronous directly applies face-to-face learning at the same time; synchronous virtually applies direct learning but is done by virtual face-to-face at the same time but in a different place; Collaborative asynchronous is learning by implementing joint learning with other people anywhere and anytime using discussion media such as blogs, chat rooms, WhatsApp groups; while independent asynchronous implements independent learning wherever and whenever using video, $\mathrm{TV}$, radio and podcast media (Bahri et al., 2020; Chaeruman \& Maudiarti, 2018). As for this pandemic, out of the four study rooms, only direct synchronization cannot be implemented.

Blended learning has three stages, namely (1) Seeking of information, seeking information from various available information sources independently asynchronously based on relevance, validity, content reliability, and academic clarity; (2) Acquisition of information finds, understands, and confronts it with ideas or ideas that already exist in the mind and then interprets the information/knowledge from various available sources until they can re-communicate and interpret the ideas and the results of their interpretation asynchronously collaboratively; (3) Synthesizing of knowledge, constructing/reconstructing knowledge through a process of assimilation and accommodation starting from the results of the analysis, discussion and formulation of conclusions from the information obtained. Return and interpret ideas and interpretation results in a synchronous virtual and asynchronous independent manner (Chaeruman \& Maudiarti, 2018; Lestari \& Siskandar, 2020).

Learning with the STEM (Science, Technology, Engineering, and Mathematics) approach is learning that integrates the four components namely science, technology, engineering, and mathematics in one learning experience helping students utilize technology 
and assemble them into experiments that can prove scientific concepts that are supported by existing data. managed mathematically (Herlina et al., 2021; Lestari \& Rahmawati, 2020). The STEM approach can make learning innovative and varied about everyday life. Students can understand the environment and problems faced by modern societies that are very dependent on the development of science and technology, including social problems (Daugherty, 2013). The STEM approach can guide and train students to think logically, critically, evaluatively, creatively in solving problems and making decisions related to dealing with life problems by utilizing technology and applying it in real life (Ceylan \& Ozdilek, 2015; Lancaster \& Cotarlan, 2021).

Blended learning with the STEM approach applied in this research is learning that emphasizes the STEM approach but is carried out in blended learning both synchronously and asynchronously by utilizing various existing technologies such as e-learning, LMS, videos, podcasts, and Television. Therefore, based on the background that has been described, this study aims to determine the application of the blended learning model with the STEM approach to improving students' scientific literacy on the subject of environmental pollution during the Covid-19 pandemic.

\section{Method}

The research method used was a pre-experiment with a one-group pretest-posttest design (Creswell, 2014). The treatment in this study is the application of blended learning with the STEM approach. The one group pretest-posttest research design is in the following table.

Table 1. Research design one group pretest-posttest.

$\mathrm{O}_{1} \mathrm{X}$
Information:
$\mathrm{O} 1$ : Test students' scientific literacy skills before learning
$\mathrm{O} 2$ : Test students' scientific literacy skills after learning
$\mathrm{X}$ : Application of blended learning with the STEM approach

The research subjects involved were 56 students of class X IPA 1 and X IPA 2 at SMAN 1 Bojong Gede, as many as 56 students in the academic year 2020-2021 odd who had been selected as purposive sampling. The research instrument used was a matter of scientific literacy in the form of a multiple-choice test on the subject of functions. Scientific literacy is developed based on indicators to identify scientific issues, explain scientific phenomena, and use scientific evidence (Lestari \& Siskandar, 2020). The student science literacy lattice is presented in Table 2.

Table 2. Students' Science Literacy Grid Ability

\begin{tabular}{lll}
\hline No & $\begin{array}{l}\text { Measured Scientific Competence in } \\
\text { Scientific Literacy }\end{array}$ & Indicator \\
\hline $1 . \quad$ Identify scientific issues (problems) & $\begin{array}{l}\text { Identify a valid scientific opinion (e.g. an opinion/theory to support a } \\
\text { hypothesis) } \\
\text { Performing an effective literature search (e.g. evaluating the validity of sources } \\
\text { and differentiating between types of sources) }\end{array}$ \\
2. Describe scientific phenomena & $\begin{array}{l}\text { Graphs precisely from data } \\
\text { Solve problems using quantitative skills, including basic statistics (e.g. } \\
\text { calculating mean, probability, percentage, frequency) } \\
\text { Understand and interpret basic statistics (interpret errors, understand the need } \\
\text { for statistical analysis) } \\
\text { Make inferences, predictions, and draw conclusions based on quantitative data }\end{array}$ \\
\hline
\end{tabular}

The data processing technique was carried out descriptively by calculating the mean and percentage of each item to obtain a description of the students' scientific literacy skills, then the data were analyzed inferentially with a paired sample t-test using SPSS version 22 software, to see differences in scientific literacy before and after blended learning. learning with the STEM approach.

\section{Result and Discussion}

The data were analyzed statistically descriptive, and the average data obtained were students' scientific literacy skills, before and after blended learning with the STEM approach as seen in Figure 1 below.

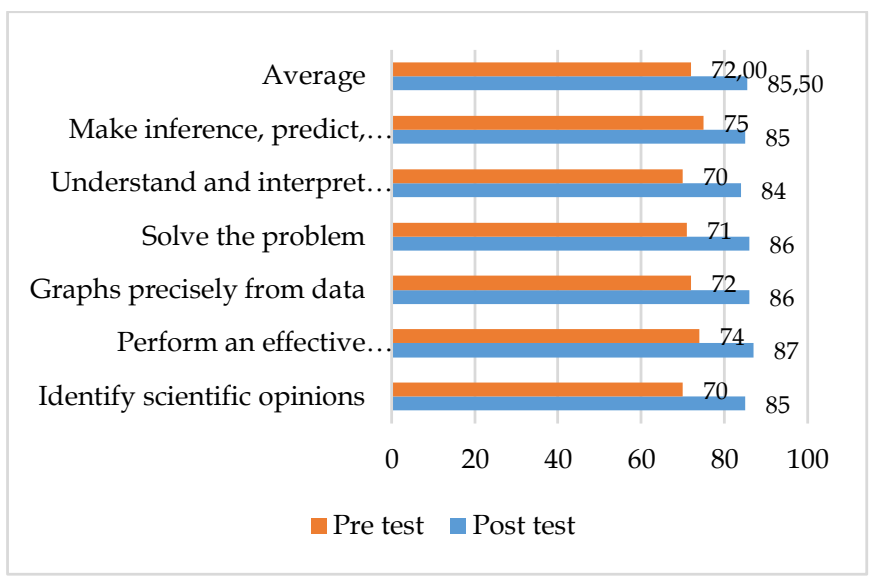

Figure 1. The Average Score of Students' Science Literacy Ability for Each Indicator 
Figure 1 shows that there is an increase in students' scientific literacy skills before and after blended learning with the STEM approach. The previous average of scientific literacy was 72.00 , becoming 85.50 . It can be concluded that there are differences in students' scientific literacy skills before and after blended learning with the STEM approach. To determine whether there is a significant difference in scientific literacy before and after the provision of blended learning with the STEM approach, the data was tested with a paired sample t-test using SPSS 22 software at a (0.05), and the following output was obtained:

Table 3. Results of Paired Sample T-Test

\begin{tabular}{lllll}
\hline & $\mathrm{N}$ & Mean & $\begin{array}{l}\text { Standar } \\
\text { Deviasi }\end{array}$ & Sig (2-Tailed) \\
\hline Pre Test & 52 & 72.00 & 0.15 & 0.000 \\
Post Test & 52 & 85.50 & 0.08 & \\
\hline
\end{tabular}

Getting a probability value (sig) of 0.000 smaller a (0.05), then Ho is rejected and H1 is accepted, meaning that the results of the study indicate that there is a significant difference in students' scientific literacy skills in the pretest and post-test. The average score of the test shows that the post-test scores are higher than before. sources related to science topics that are up to date in society through videos, TV, radio or podcasts. which has been directed and determined by the teacher. The aspects of the STEM approach that are trained are science and technology aspects. The scientific literacy skills trained at this stage are the ability to carry out effective literature searches with a percentage of $87 \%$ meaning that students are good at reading and browsing literature related to the topic being studied and indicators identify scientific opinions with a percentage of $85 \%$ meaning that students are good enough at understanding scientific opinion that builds on the material being studied.

The second stage is the Acquisition of information; At this stage students develop an empirical attitude by making observations, discussions with the work ethic, and creativity through collaborative asynchronous activities, namely making observations about the topic being studied (topics are given by the teacher for each group), students formulating problems, proposing hypotheses, and writing how to work, record data from observations, conclude the results of observations in an asynchronous collaborative manner by recording these activities then upload them on the blog and the results of group discussions are sent to the teacher's blog and students are allowed to respond to the results of the discussion through the teacher's comment column. The aspects of the STEM approach that are trained are science, technology, engineering, and mathematics (Sasmita et al., 2021). At this stage, the
Therefore, these findings indicate that students' scientific literacy skills, after the blended learning intervention using the STEM approach, have increased.

The results of data analysis showed that students 'scientific literacy skills after the learning process had increased significantly because each indicator of students' scientific literacy skills was developed through blended learning with the STEM approach. Blended learning is applied in a virtual synchronous manner, namely direct learning is carried out with virtual face-toface at the same time but in different places through media zoom meetings as well as independently and collaboratively asynchronously with indirect learning (not at the same time) both asynchronous collaborative media discussions with blogs, chat rooms, WhatsApp groups and asynchronously independently using video, TV, radio and podcast media (Chaeruman \& Maudiarti, 2018).

Blended learning with the STEM approach has three stages, namely the first stage, namely Seeking information; At this stage students develop students' scientific knowledge from social, cultural, or community values through asynchronous independent activities where students study and seek references from various scientific literacy skills trained are to understand and interpret basic statistics, make graphs appropriately from data, solve problems. For indicators of scientific literacy to understand and interpret basic statistics with a percentage of $84 \%$, it means that the ability of students in the good category to interpret basic statistics from the results of observations. The indicator makes graphs appropriately from the data with a percentage of $86 \%$, meaning that students are good at making graphs from the observations obtained during observation and discussion activities. The indicator of solving problems with a percentage of $86 \%$ means that students are already good at solving problems from the results of discussions, observations and observations made.

The third stage is Synthesizing Knowledge; at this stage students work together and collaborate to present the results of group discussions and the teacher together concludes the material studied in this learning in virtual synchronous activities through zoom meetings as well as independently asynchronously with students uploading the final results of the presentation discussion and the conclusion of the learning outcomes of the online LMS page. At this stage the students' scientific literacy skills are trained to make an inference, predict and draw conclusions and get a percentage of $85 \%$, which means that students are good at concluding discussions and observations. As for the implementation stage of stem-based blended learning as follows. 

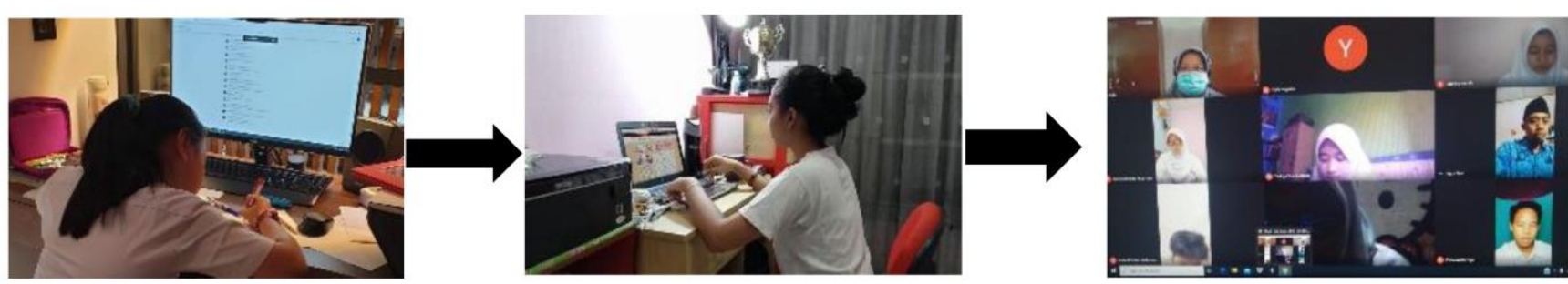

Sten 1: Sepkino of information
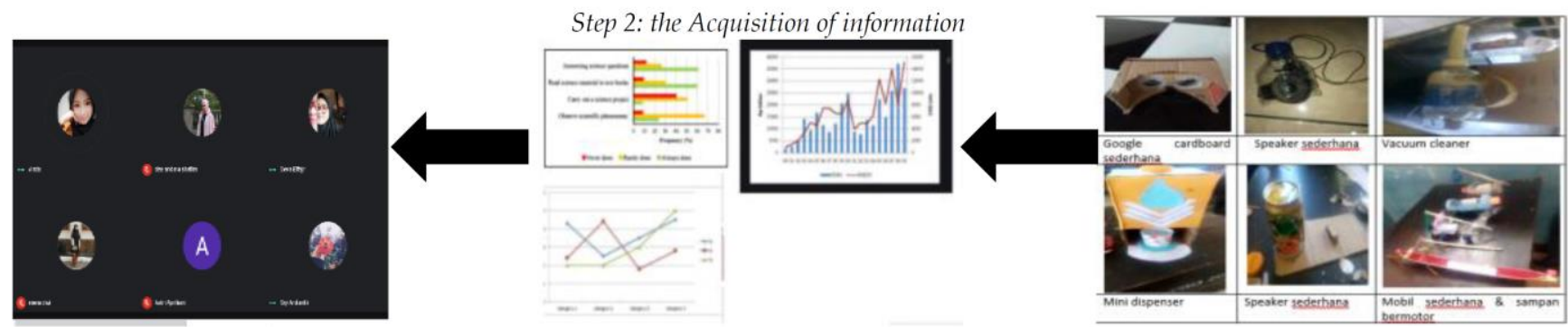

Step 3: Synthesizing Knowledge

Fig. 1. Implementation stage of stem-based blended learning

Based on the results of the research, the three stages of blended learning are oriented towards the STEM approach, facilitating all aspects of science (students are required to be able to use the natural knowledge they acquire in solving a problem in their daily lives), technology (students are required to be able to collaborate in the use of technology) (Sasmita et al., 2021). to convey information and to process the data found), techniques (students collaborate their findings to find appropriate solutions or even create a product), and mathematics (students can use their mathematical knowledge when they process data) by utilizing existing technology both synchronous and asynchronous (Alamri \& Watson, 2020; Han et al., 2016).

Blended learning with the STEM approach offers the potential to improve the teaching and learning process in an educational environment that is responsive to the lifestyle of contemporary students (Dziuban et al., 2018; Yusuf et al., 2021). Technological innovation extends the range of learning solutions, creates more effective learning experiences, increases access and flexibility, or reduces learning costs, this is very suitable for learning conditions in the new normal era which require innovation and creativity to manage to learn, learning that can be accessed easily. and is flexible (Bryan, Volchenkova, 2016). With the implementation of synchronous and asynchronous learning with a STEM approach, of course, it utilizes information technology which of course will change the direction of pedagogy into digital pedagogy. Digital pedagogy influences the teaching style and strategy of teachers in utilizing the four aspects of the STEM approach, namely aspects of science, technology, engineering, and mathematics.
Research conducted by Budiharti (2015) states that blended learning can improve students' mastery of concepts and reasoning. Whereas the STEM approach refers to principles and ideas that provide a valid description of science as a way of knowing and the characteristics of scientific knowledge development contain four things, namely: content or products, processes or methods, attitudes, and technology (Gordy et al., 2021; Lestari \& Rahmawati, 2020). The STEM approach is an approach to learning to acquire knowledge, or the values and beliefs inherent in scientific knowledge and the development of students' scientific literacy skills through observing activities, formulating relevant questions, evaluating books and other sources of information critically, plan an investigation or investigation, review what is known, carry out experiments or experiments using tools to obtain data, analyze and interpret data, and make predictions and communicate the results with the help of digital tools and technologies such as blogs, websites, and social media today with combines synchronous and asynchronous online learning (Soler et al., 2017; Zulirfan et al., 2020)

\section{Conclusion}

The results of this study concluded that students' mastery of the concept before using the inductive empirical type learning cycle model on the concept of low plant transportation. This is based on the data from the pre-test scores carried out in the experimental class and the control class. Students' mastery of the concept after using the inductive empirical learning cycle model 
has increased. There is an increase in the average posttest score in the experimental class students. The difference in students' conceptual mastery in a class that uses an inductive empirical learning cycle with a control class is significantly different. This means that the students' mastery of the concept of the experimental class is higher than the control class who uses ordinary practicum. Students' attitudes about the use of the inductive empirical learning cycle model received a positive response. Almost all students like learning using the empirical inductive learning cycle model.

\section{References}

Alamri, H. A., \& Watson, W. (2020). Learning Technology Models that Support Personalization within Blended Learning Environments in Higher Education. TechTrends, 65(1), 62-78. https://doi.org/https://doi.org/10.1007/s11528 -020-00530-3

Arlis, S., Amerta, S., Indrawati, T., Zuryanty, Z., Chandra, C., Hendri, S., Kharisma, A., \& Fauziah, M. (2020). Literasi Sains Untuk Membangun Sikap Ilmiah Siswa Sekolah Dasar. Jurnal Cakrawala Pendas, 6(1), 1-14. https://doi.org/10.31949/jcp.v6i1.1565. [Indonesian]

Bahri, A., Idris, I. S., Muis, H., Arifuddin, M., \& Fikri, M. J. N. (2020). Blended Learning Integrated with Innovative Learning Strategy to Improve SelfRegulated Learning. International Journal of Instruction, 14(1), 779-794. https://doi.org/10.29333/IJI.2021.14147A

Berga, K. A., Vadnais, E., Nelson, J., Johnston, S., Buro, K., Hu, R., \& Olaiya, B. (2021). Blended learning versus face-to-face learning in an undergraduate nursing health assessment course: A quasiexperimental study. Nurse Education Today, 96(August 2020), 104622. https://doi.org/10.1016/j.nedt.2020.104622

Borup, J., Chambers, C., \& Srimson, R. (2019). Online teacher and on-site facilitator perceptions of parental engagement at a supplemental virtual high school. International Review of Research in Open and Distance Learning, 20(2), 79-95. https://doi.org/10.19173/irrodl.v20i2.4237

Bryan, Volchenkova, K. . (2016). Blended Learning: Definition, Models, Implications for Higher Education. Education Sciences, 8(2), 24-30. https://doi.org/10.14529/ped160204

Budiharti, R., Ekawati, E. Y., Wahyuningsih, D., \& H, F. F. (2015). Penggunaan Blended Learning dengan Media Moodle untuk Meningkatkan Kemampuan Kognitif Siswa SMP. Jurnal Cakrawala Pendidikan,
1(1), 140-148. https://doi.org/10.21831/cp.v1i1.4184.

[Indonesian]

Ceylan, S., \& Ozdilek, Z. (2015). Improving a Sample Lesson Plan for Secondary Science Courses within the STEM Education. Procedia - Social and Behavioral Sciences, 177(July 2014), 223-228. https://doi.org/10.1016/j.sbspro.2015.02.395

Chaeruman, U. A., \& Maudiarti, S. (2018). Quadrant of Blended Learning: a Proposed Conceptual Model for Designing Effective Blended Learning. Jurnal Pembelajaran Inovatif, 1(1), 1-5. https://doi.org/10.21009/jpi.011.01

Creswell, J. W. (2014). Four Edition Research Design: Qualitative, Quantitative, and Mixed Methods Approaches. University of Nebraska Lincoln.

Daugherty, M. K. (2013). The Prospect of an "A" in STEM Education. Journal of STEM Education: Innovations and Research, 14(2), 10-15.

Dhawan, S. (2020). Online Learning: A Panacea in the Time of COVID-19 Crisis. Journal of Educational Technology Systems, 49(1), 5-22. https://doi.org/10.1177/0047239520934018

Dziuban, C., Graham, C. R., Moskal, P. D., Norberg, A., \& Sicilia, N. (2018). Blended learning: the new normal and emerging technologies. International Journal of Educational Technology in Higher Education, 15(1), 1-16. https://doi.org/10.1186/s41239-017-0087-5

Fauzi, I., \& Sastra Khusuma, I. H. (2020). Teachers' Elementary School in Online Learning of COVID19 Pandemic Conditions. Jurnal Iqra' : Kajian Ilmu Pendidikan, 5(1), 58-70. https://doi.org/10.25217/ji.v5i1.914

Fitriyana, N., Wiyarsi, A., Ikhsan, J., \& Sugiyarto, K. H. (2020). Android-based-game and blended learning in chemistry: Effect on students' selfefficacy and achievement. Cakrawala Pendidikan, 39(3), 507-521. https://doi.org/10.21831/cp.v39i3.28335

Gordy, X. Z., Sparkmon, W., Imeri, H., Notebaert, A., Barnard, M., Compretta, C., Dehon, E., Taylor, J., Stray, S., Sullivan, D., \& Rockhold, R. W. (2021). education sciences Science Teaching Excites Medical Interest: A Qualitative Inquiry of Science Education during the 2020 COVID-19 Pandemic. Education Sciences, 11(4), 148. https://doi.org/https://doi.org/10.3390/educs ci11040148

Han, S., Rosli, R., Capraro, M. M., \& Capraro, R. M. (2016). The effect of Science, technology, engineering and mathematics (STEM) project based learning (PBL) on students' Achievement in four mathematics topics. Journal of Turkish Science Education, 13(Specialissue), 3-30. 
https:// doi.org/10.12973/tused.10168a

Hasasiyah, S. H., Hutomo, B. A., Subali, B., \& Marwoto, P. (2019). Analisis Kemampuan Literasi Sains Siswa SMP pada Materi Sirkulasi Darah. Jurnal Penelitian Pendidikan IPA, 6(1), 5. https://doi.org/10.29303/jppipa.v6i1.193 [Indonesian]

Herlina, Lagandesa, Y. R., Azizah, \& Asriani. (2021). Training and implementation of google applications for online learning in the pandemic covid-19. Journal of Physics: Conference Series, 1832(1), 012049. https://doi.org/10.1088/17426596/1832/1/012049

Jamaluddin, J., Jufri, A. W., Ramdani, A., \& Azizah, A. (2019). Profil Literasi Sains Dan Keterampilan Berpikir Kritis Pendidik IPA SMP. Jurnal Penelitian Pendidikan IPA, $5(1)$. https://doi.org/10.29303/jppipa.v5i1.185 [Indonesian]

Jarwati, \& Priskawati, D. (2020). Blended Learning: Solusi Pembelajaran New Normal Untuk Pendidikan Agama Kristendi Era Revolusi Industri 4.0. Jurnal Pendidikan DIDAXEI, 1(2), 103-113. [Indonesian]

Komalasari, B. S., Jufri, A. W., \& Santoso, D. (2019). Pengembangan Bahan Ajar IPA Berbasis Inkuiri Terbimbing untuk Meningkatkan Literasi Sains. Jurnal Penelitian Pendidikan IPA, 5(2), 219. https://doi.org/10.29303/jppipa.v5i2.279

[Indonesian]

Lancaster, T., \& Cotarlan, C. (2021). Contract cheating by STEM students through a file sharing website: a Covid-19 pandemic perspective. International Journal for Educational Integrity, 17(1), 1-16. https://doi.org/10.1007/s40979-021-00070-0

Lestari, H., Banila, L., \& Siskandar, R. (2019). Kemandirian Belajar Melalui Pembelajaran Berbasis STEM Improving Student' S Science Literacy Competencies Based On Learning Independence With Stem Learning. Biodidaktika. 14(2), 18-23. [Indonesian]

Lestari, H., \& Rahmawati, I. (2020). Integrated STEM through Project Based Learning and Guided Inquiry on Scientific Literacy Abilities in Terms of Self-Efficacy Levels. Al Ibtida, 7(1), 19-32.

Lestari, H., Setiawan, W., \& Siskandar, R. (2020). Science Literacy Ability of Elementary Students Through Nature of Science-based Learning with the Utilization of the Ministry of Education and Culture' s " Learning House ". Jurnal Penelitian Pendidikan IPA, 6(2), 215-220. https://doi.org/10.29303/jppipa.v6i2.410

Lestari, H., \& Siskandar, R. (2020). Literasi Sains Siswa Melalui Penerapan Model Pembelajaran Blended Learning Dengan Blog. NATURALISTIC: Jurnal
Kajian Penelitian Pendidikan, 4(2), 597-604. https://journal.umtas.ac.id/index.php/naturalist ic/article/view/769 [Indonesian]

Lestari, H., \& Widodo, A. (2021). Peranan Model Pembelajaran Nature of Sains Untuk Meningkatkan Pemahaman Sains Siswa Sekolah Dasar. Jurnal Cakrawala Pendas, 7(1), 1-9. [Indonesian]

Rahmadani, D., Chastanti, I., \& Harahap, D. A. (2021). Parents' Role in Biology Learning During the Covid 19 Pandemic. Jurnal Penelitian Pendidikan IPA, 7(March 2020), 0-5. https://doi.org/10.29303/jppipa.v7i2.583

Ramdani, A., Jufri, A. W., Gunawan, G., Hadisaputra, S., \& Zulkifli, L. (2019). Pengembangan Alat Evaluasi Pembelajaran IPA Yang Mendukung Keterampilan Abad 21. Jurnal Penelitian Pendidikan IPA,

https://doi.org/10.29303/jppipa.v5i1.221

5(1). [Indonesian]

Richardson, J. W., Lingat, J. E. M., Hollis, E., College, R., \& Pritchard, M. (2020). Shifting teaching and learning in online learning spaces: An investigation of a faculty online teaching and learning initiative. Online Learning Journal, 24(1), 67-91. https://doi.org/10.24059/olj.v24i1.1629

Sasmita, D., Adlim, M., Gani, A., \& Syukri, M. (2021). Implementation of STEM-based Student Worksheet to Increase Student Entrepreneurial Innovation through the Development of Candied Nutmeg Products. Jurnal Penelitian Pendidikan IPA, 7(1),

112. https://doi.org/10.29303/jppipa.v7i1.551

Setiawan, B., \& Iasha, V. (2020). Corona Virus Disease 2019: The Perspective Opinion From Pre-Service Elementary Education Teacher. Education, Sustainability \& Society, 3(2), 33-36. https://doi.org/10.26480/ess.02.2020.33.36

Soler, R., Soler, J. R., \& Araya, I. (2017). Subjects in the Blended Learning Model Design. TheoreticalMethodological elements. Procedia - Social and Behavioral Sciences, 237(June 2016), 771-777. https://doi.org/10.1016/j.sbspro.2017.02.120

Sopandi, W. (2019). Sosialisasi dan Workshop Implementasi Model Pembelajaran RADEC Bagi Guru-Guru Pendidikan Dasar dan Menengah [Dissemination and Implementation Workshop of RADEC Learning Models for Primary and Secondary Education Teachers]. PEDAGOGIA: Jurnal Pendidikan, 8(1), 19. https://doi.org/10.21070/ pedagogia.v8i1.1853 [Indonesian]

Yuliati, Y. (2017). Literasi Sains Dalam Pembelajaran Ipa. Jurnal Cakrawala Pendas, 3(2), 21-28. https://doi.org/10.31949/jcp.v3i2.592 
[Indonesian]

Yusuf, A. R., Student, P. G., Engineering, F., \& Malang, U. N. (2021). Implementation of Online STEM-PjBL through Various Learning Platforms in Vocational High Schools during Covid-19 Pandemic. Ilköğretim Online, 20(2), 1-8. https://doi.org/10.17051/ilkonline.2021.02.04

Zuhara, E., Jufri, A. W., \& Soeprianto, H. (2019). Kemampuan Literasi Biologi Berdasarkan Gender Pada Siswa Peminatan Mipa Di Sma Negeri Kabupaen Lombok Barat. Jurnal Penelitian Pendidikan IPA, 5(1), 115-119. https://doi.org/10.29303/jppipa.v5i1.234 [Indonesian]

Zulirfan, Z., Yennita, Y., \& Rahmad, M. (2020). STEM at Home: Provide Scientific Activities for Students during the Covid-19 Pandemic. Journal of Physics: Conference Series, https://doi.org/10.1088/17426596/1655/1/012068 